\title{
c-Myc overexpression sensitises colon cancer cells to camptothecin-induced apoptosis
}

\author{
D Arango*,', JM Mariadason', AJ Wilson', W Yang', GA Corner', C Nicholas', MJ Aranes' and LH Augenlicht' \\ 'Albert Einstein Cancer Center, Montefiore Medical Center, Oncology Department, 1 I I East 21 Oth St, Bronx, NY 10467, USA
}

\begin{abstract}
The proto-oncogene c-Myc is overexpressed in $70 \%$ of colorectal tumours and can modulate proliferation and apoptosis after cytotoxic insult. Using an isogenic cell system, we demonstrate that c-Myc overexpression in colon carcinoma LoVo cells resulted in sensitisation to camptothecin-induced apoptosis, thus identifying c-Myc as a potential marker predicting response of colorectal tumour cells to camptothecin. Both camptothecin exposure and c-Myc overexpression in LoVo cells resulted in elevation of p53 protein levels, suggesting a role of p53 in the c-Myc-imposed sensitisation to the apoptotic effects of camptothecin. This was confirmed by the ability of PFT- $\alpha$, a specific inhibitor of $\mathrm{p} 53$, to attenuate camptothecin-induced apoptosis. p53 can induce the expression of $\mathrm{p} 2 \mathrm{I}^{\mathrm{Wafl} / \mathrm{Cip} /}$, an antiproliferative protein that can facilitate DNA repair and drug resistance. Importantly, although camptothecin treatment markedly increased $\mathrm{p} 2 \mathrm{I}^{\text {Wafl/Cipl }}$ levels in parental LoVo cells, this effect was abrogated in c-Mycoverexpressing derivatives. Targeted inactivation of $\mathrm{p} 2 \mathrm{I}^{\mathrm{Wafl} / \mathrm{Cipl}}$ in $\mathrm{HCT} \mathrm{I} / 6$ colon cancer cells resulted in significantly increased levels of apoptosis following treatment with camptothecin, demonstrating the importance of $\mathrm{p} 2 \mathrm{I}^{\text {Wafl/Cipl }}$ in the response to this agent. Finally, cDNA microarray analysis was used to identify genes that are modulated in expression by c-Myc upregulation that could serve as additional markers predicting response to camptothecin. Thirty-four sequences were altered in expression over four-fold in two isogenic c-Myc-overexpressing clones compared to parental LoVo cells. Moreover, the expression of 10 of these genes was confirmed to be significantly correlated with response to camptothecin in a panel of 30 colorectal cancer cell lines.
\end{abstract}

British Journal of Cancer (2003) 89, I757- |765. doi:I0.1038/sj.bjc.660I338 www.bjcancer.com

(C) 2003 Cancer Research UK

Keywords: camptothecin; apoptosis; microarray; p2 I Wafl/Cipl

The tumour-suppressor gene p53 plays a pivotal role in determining cell fate after cytotoxic insult with DNA-damaging agents. p53 is a transcription factor that can either trigger an apoptotic cell death by transcriptionally modulating multiple target genes, or promote cell cycle arrest, and thus facilitate DNA damage repair, through the upregulation of the cyclin-dependent kinase (cdk) inhibitor p $21^{\text {Wafl/Cipl }}$ (el-Deiry et al, 1993; Miyashita et al, 1994). Recently, levels of the proto-oncogene c-Myc have been shown to be critical in switching the p53-dependent response from cell cycle arrest to apoptosis after gamma radiation or treatment with daunorubicin (Seoane et al, 2002), a topoisomerase II inhibitor that is not frequently used for the treatment of colorectal malignancies (Harvey et al, 1985). These effects are mediated through the ability of c-Myc to interact with Miz-1 and downregulate the expression of $\mathrm{p} 21^{\text {Wafl/Cip1, }}$, thus favouring the proapoptotic activities of $\mathrm{p} 53$. Previously, we demonstrated the clinical value of $c-m y c$ as a marker that predicts response to treatment with 5-fluorouracil (5FU), the standard chemotherapeutic agent used in the treatment of colorectal cancer (O'Dwyer and Stevenson, 1998). Low-level amplification of $c-m y c$, together with a wild-type $p 53$ gene, identified a subset of patients with locally

\footnotetext{
* Correspondence: Dr D Arango; Current address: Department of Medical Genetics, Biomedicum Helsinki, Room B520a, PO Box 63 (Haartmaninkatu 8), FIN-000I4 University of Helsinki, Finland; E-mail: diego.arango@helsinki.fi

Received 3 July 2003; revised 27 August 2003; accepted 28 August 2003
}

advanced colorectal cancer showing increased disease-free and overall survival in response to 5FU-based adjuvant therapy (Augenlicht et al, 1997; Arango et al, 2001).

Camptothecin is a topoisomerase I inhibitor that interferes with DNA replication and transcription by stabilising the covalent complex formed between Topoisomerase I and DNA. The camptothecin derivative CPT-11 (Irinotecan) has been shown to be a useful chemotherapeutic agent for the treatment of colorectal cancer patients, improving response rates and survival when used in combination with $5 \mathrm{FU}$, and has also been shown to be effective in 5FU-resistant tumours (Cunningham et al, 1998; Douillard et al, 2000; Arango and Augenlicht, 2001). Recently, there has been significant progress in the identification of genetic markers that allow prediction of response to 5FU and/or oxaliplatin, which together with CPT-11 are the main chemotherapeutic agents used in the treatment of colorectal cancer (Augenlicht et al, 1997; Salonga et al, 2000; Arango et al, 2001, 2003; Park et al, 2001; Shirota et al, 2001). However, there is great need for markers predicting the efficacy of CPT-11 treatment. In this study, we hypothesised that the levels of c-Myc could modulate the cellular response to camptothecin. Using an in vitro isogenic system, we demonstrated the important role of $\mathrm{c}-\mathrm{Myc}$ in the apoptotic response of colon cancer cells to camptothecin. Understanding of the molecular mechanisms underlying this observation would allow significant insight to be gained into the key determinants of response to chemotherapy and could identify new targets for intervention. Here we demonstrate a p53-dependent component in 
the c-Myc-imposed sensitisation to camptothecin-induced apoptosis. Moreover, forced expression of c-Myc resulted in reduced levels of $\mathrm{p} 21^{\text {Waf1/Cip } 1}$ despite elevated levels of $\mathrm{p} 53$, and targeted inactivation of $\mathrm{p} 21^{\text {Wafl/Cipl }}$ resulted in increased sensitivity to apoptosis induced by this agent.

Finally, to identify additional markers capable of predicting apoptotic response to this agent, we used a cDNA microarray analysis approach. The levels of expression of 9216 sequences were assessed in camptothecin-resistant LoVo colon carcinoma cells and camptothecin-sensitive isogenic derivatives overexpressing cMyc. Thiry-four sequences were identified exhibiting over 4-fold difference in expression. The potential of 10 of these genes as markers predicting response to camptothecin was confirmed by the significant correlation observed between the levels of expression of these genes and the extent of apoptosis induced by camptothecin in a panel of 30 different colorectal cancer cell lines.

\section{MATERIALS AND METHODS}

\section{Cell lines and culture conditions}

Colon adenocarcinoma LoVo cells and two isogenic clones overexpressing c-Myc (L2 and L3) have been extensively characterised and were maintained as described (Arango et al, 2001). TGR1 rat fibroblasts, isogenic HO15-19 cells with targeted disruption of both alleles of $c-m y c$, and HOmyc 3 cells in which cMyc expression has been restored in the knockout cells (Mateyak et al, 1997) were kindly provided by Dr Sedivy (Brown University, RI, USA) and maintained with DMEM supplemented with $10 \%$ FBS and $1 \times$ antibiotic/antimycotic (Invitrogen, Carlsbad, CA, USA). HCT116, a colon carcinoma cell line with a functional p53 gene, and an isogenic line with a targeted inactivation of $\mathrm{p} 21^{\text {Wafl/Cip } 1}$ (Bunz et al, 1998) were kind gifts of Dr Vogelstein (Johns Hopkins University School of Medicine). The panel of colorectal cancer cell lines used was: Caco-2, Colo201, Colo205, Colo320, DLD-1, HCT116, HCT-15, HCT-8, LoVo, LS174T, RKO, SK-CO-1, SW1116, SW403, SW48, SW480, SW620, SW837, SW948, T84 and WiDr (all from the American Type Culture Collection, Manassas, VA, USA), HT29, HT29-Cl.16E, HT29-Cl.19A (from Dr Laboisse, Institut National de la Sante et de la Recherche Medicale U539, France (Augeron and Laboisse, 1984)), LIM1215, LIM2405 (from Dr Whitehead, Vanderbilt University, Nashville, TN, USA (Whitehead et al, 1985; Devine et al, 1992)), HCC2998, KM12 (from the NCI-Frederick Cancer DCT tumour repository), RW2982 and RW7213 (Tibbetts et al, 1988). All the colorectal cancer cell lines were maintained in MEM supplemented with $10 \%$ FBS and $1 \times$ antibiotic/antimycotic (Invitrogen, Carlsbad, CA, USA).

\section{Quantification of apoptosis}

$1 \times 10^{5}$ cells were seeded in triplicate in six-well plates and $24 \mathrm{~h}$ later treated with the indicated concentrations of camptothecin (Calbiochem, La Jolla, CA, USA). In some experiments, Pifithrin- $\alpha$ (PFT- $\alpha$; Calbiochem, La Jolla, CA, USA), a specific p53 inhibitor (Komarov et al, 1999), was also added at time $0(15-30 \mu \mathrm{M})$. The apoptotic response to camptothecin treatment was quantified after $72 \mathrm{~h}$ by propidium iodide (PI) staining and assessment of the proportion of cells with a subdiploid content of DNA by FACS analysis, as described (Arango et al, 2001).

\section{Western blot analysis}

Both untreated and camptothecin-treated cultures $(0.1$ or $0.5 \mu \mathrm{M}$ for $24 \mathrm{~h}$ ) growing in T75 flasks were rinsed twice with PBS, harvested and the pellet resuspended in $300 \mu \mathrm{l}$ of RIPA buffer $(1 \%$ NP-40, $1 \%$ sodium deoxycholate, $0.1 \%$ SDS, $0.15 \mathrm{M} \mathrm{NaCl}, 0.01 \mathrm{M}$ sodium phosphate $\mathrm{pH} 7.2,2 \mathrm{~mm}$ EDTA, $50 \mathrm{~mm}$ sodium fluoride, $0.2 \mathrm{~mm}$ sodium vanadate and $100 \mathrm{U} \mathrm{ml}^{-1}$ aprotinin), lysed for
$30 \mathrm{~min}$ on ice, and cleared by centrifugation. The appropriate volume of Laemmli loading buffer $(6 \times)$ was added to $100 \mu \mathrm{g}$ aliquots and fractionated in $15 \%$ SDS-polyacrylamide gels. Proteins were transferred to a PVDF membrane (Amersham, Piscataway, NJ, USA), blocked with $10 \%$ nonfat milk for $1 \mathrm{~h}$ and then probed at room temperature with the appropriate primary antibody in 5\% nonfat milk for $1 \mathrm{~h}$. The following antibodies and dilutions were used: anti-p53 and anti-p21 $1^{\text {Waf1/Cip1 }}$ (DO-1, 1/7000 and H-164, 1/200, respectively; Santa Cruz Biotechnology, Santa Cruz, CA, USA), anti- $\beta$-actin (clone AC74, 1/1000; Sigma, Saint Louis, MO, USA). Membranes were washed three times with washing buffer (PBS with $0.1 \%$ Tween 20 ) and then probed with a peroxidase-conjugated secondary antibody for $1 \mathrm{~h}$ (Boehringer Mannheim, Indianapolis, IN, USA). After washing three times with washing buffer, the signal was detected using ECL plus (Amersham, Piscataway, NJ, USA) and a Storm PhosphorImager (Molecular Dynamics, Sunnyvale, CA, USA). The signal from the $\beta$-actin probe was used as a loading control.

\section{p21 Waf1/Cip1 promoter activity}

$\mathrm{p} 21^{\text {Waf1/Cip } 1}$ promoter activity was measured in parental LoVo cells and c-Myc-transfected L2 and L3 cells using a transient transfection assay. The p21P construct (Datto et al, 1995) has a $2.4 \mathrm{~kb}$ insert containing the $\mathrm{p} 21^{\text {Waf1/Cip1 }}$ promoter sequences in pGL2basic (Promega, Madison, WI, USA), driving transcription of a firefly luciferase reporter gene. LoVo, L2 and L3 cells $\left(5 \times 10^{4}\right.$ per well) were seeded in 24-well plates and cotransfected with p21P and TK-Renilla (Promega, Madison, WI, USA) $24 \mathrm{~h}$ later using GenePORTER II (Gene Therapy Systems, San Diego, CA, USA). After $48 \mathrm{~h}$, cells were harvested, and firefly and Renilla luciferase activity levels assessed using the Dual Luciferase kit (Promega, Madison, WI, USA) according to the manufacturer's specifications. In addition, parental LoVo cells were cotransfected with both $\mathrm{p} 21 \mathrm{P}$ and TK-Renilla as well as either p290-Myc(2,3), a c-Myc expression vector (Reed et al, 1989) or the empty p290 vector, to assess the effects of exogenous c-Myc on p $21^{\text {Waf1 }} / \mathrm{Cip}^{1}$ promoter activity. In all cases, values from TK-Renilla luciferase activity were used to correct for differences in transfection efficiency.

\section{Microarray analysis}

Parental LoVo cells as well as L2 and L3 c-Myc transfectants $\left(5 \times 10^{6}\right.$ cells $)$ were seeded in T150 flasks, and harvested after $96 \mathrm{~h}$. Total RNA was prepared using the RNeasy Midi kit (Qiagen, Valencia, CA, USA). RNA aliquots $(100 \mu \mathrm{g})$ were reverse-transcribed and labelled with $\mathrm{Cy} 5$ as described (Mariadason et al, 2000). All experimental samples were compared to a common reference RNA resulting from mixing equal amounts of total RNA from 12 different colon carcinoma cell lines. Reference RNA aliquots $(100 \mu \mathrm{g})$ were reverse-transcribed and labelled with Cy3 in parallel with the corresponding experimental samples, and then combined and hybridised to a 9216-sequence cDNA microarray from the Albert Einstein Cancer Center Microarray Facility, as described (Mariadason et al, 2000). Microarray slides were scanned and GenePix Pro 3.0 (Axon Instruments, Foster City, CA, USA) was used to quantify signal and background in the Cy5 and $\mathrm{Cy} 3$ channels for each spot, as well as the $\mathrm{Cy} 5 / \mathrm{Cy} 3$ signal ratio and a normalisation factor that centred the average ratios over the slide on 1. These data were transferred to a Microsoft Excel spreadsheet, and normalised among arrays by multiplying the Cy5/ $\mathrm{Cy} 3$ ratio by the normalisation factor, thereby allowing interarray comparison. All experiments were done in duplicate, beginning with different RNA preparations. Data from both hybridisations were averaged and used for subsequent analysis if there was a significant level of expression (defined as signal $>$ background plus two standard deviations in the $\mathrm{Cy} 5$ and/or $\mathrm{Cy} 3$ channel). Relative expression between LoVo and either L2 or L3 cells was calculated 
by dividing the corresponding average values for each sequence. These values were entered into Microsoft Access and sequences with a difference in expression greater than four-fold between LoVo, and both L2 and L3 were identified. GeneCluster and TreeView software (Stanford University) were used to visualise the results.

\section{Quantitative real-time RT-PCR}

The expression levels of 14 genes randomly selected from those identified as differentially expressed (over four-fold) in microarray experiments were confirmed using quantitative real-time RTPCR. RNA aliquots $(5 \mu \mathrm{g})$ from the same preparations used for the microarray experiments were reverse transcribed using SuperScript II (Invitrogen, Carlsbad, CA, USA). PCR primers for specific target genes were designed using Primer Express software (Applied Biosystems, Foster City, CA, USA) and used to quantify the relative gene expression (see Table 1; primer sequences available at www.realtimeprimers.org). $10 \mathrm{ng}$ cDNA aliquots from LoVo, L2 and L3 cells were amplified with specific primers using the SYBR green Core Reagents Kit and a 7900HT real-time PCR instrument (Applied Biosystems, Foster City, CA, USA). Expression of each gene was standardised using GAPDH as a reference, and relative levels in LoVo, L2 and L3 cells were quantified calculating $2^{-\Delta \Delta C_{\mathrm{T}}}$, where $\Delta \Delta C_{\mathrm{T}}$ is the difference in $C_{\mathrm{T}}$ (cycle number at which the amount of amplified target reaches a fixed threshold) between target and reference, relative to parental LoVo cells.

\section{RESULTS}

Overexpression of c-Myc sensitises colon carcinoma cells to apoptosis induced by camptothecin

To investigate the possible role of $\mathrm{c}-\mathrm{Myc}$ in determining the apoptotic response of colon cancer cells to camptothecin, we used an isogenic in vitro system engineered by stably introducing a cMyc expression vector into the LoVo colon cancer cell line (Arango et al, 2001). Two different derivative clones, L2 and L3, have been extensively characterised and shown to have c-Myc levels three- and eight-fold higher than parental LoVo cells, respectively, and correspondingly increased c-Myc transactivation activity levels (Arango et al, 2001). Quantification of the number of apoptotic cells after exposure to 100 or $1000 \mathrm{~nm}$ camptothecin for $72 \mathrm{~h}$ demonstrated that the higher c-Myc levels in L2 and L3 cells resulted in significantly $(P<0.0001)$ increased apoptosis induced by this agent (Figure 1).

To further confirm the observed c-Myc-induced sensitisation to the apoptotic effects of camptothecin, we used TGR1 rat fibroblasts and their derivative, HO15-19 cells, which contain a homozygous deletion of the $c-m y c$ gene (Mateyak et al, 1997). In agreement with

Table I Genes differentially expressed in parental LoVo cells and c-Myc-overexpressing L2 and L3 isogenic cells

\begin{tabular}{|c|c|c|c|c|c|c|c|c|}
\hline \multirow[b]{2}{*}{ Accession } & \multirow[b]{2}{*}{ Gene name } & \multirow[b]{2}{*}{ Function } & \multicolumn{2}{|c|}{ Microarray $^{a}$} & \multicolumn{2}{|c|}{$\mathbf{R T}-\mathbf{P C} \mathbf{R}^{\mathbf{b}}$} & \multicolumn{2}{|c|}{ Correlation $^{c}$} \\
\hline & & & L2/L & $\mathbf{L} 3 / \mathbf{L}$ & L2/L & L3/L & $r$ & $P$ \\
\hline AA08886I & Cadherin 17, LI cadherin (liver-intestine) & Cell adhesion & 0.23 & 0.18 & 0.006 & 0.023 & -0.16 & \\
\hline AAI30579 & Lectin, galactoside-binding, soluble, 4 (galectin 4) & Cell adhesion & 7.14 & 10.89 & & & 0.33 & \\
\hline N30868 & Integrin, alpha 4 & Cell adhesion & 4.75 & 6.87 & & & 0.48 & 0.016 \\
\hline R60995 & Coagulation factor $\mathbf{C}$ homologue, cochlin & Cell communication & 0.12 & 0.17 & & & -0.54 & 0.002 \\
\hline AA453783 & Mal, T-cell differentiation protein 2 & Development-differentiation & 6.26 & 4.5 & & & 0.35 & \\
\hline HI7696 & Myelin basic protein & Development-differentiation & 12.03 & 10.41 & 0.260 & 0.350 & -0.09 & \\
\hline AA290737 & Glutathione S-transferase MI & Drug metabolism/resistance & 0.17 & 0.25 & 0.002 & 0.012 & -0.43 & 0.019 \\
\hline H2952I & ATP-binding cassette 3 & Drug metabolism/resistance & 0.14 & 0.19 & 0.003 & 0.001 & -0.09 & \\
\hline H88329 & Calbindin I, (28 kDa) & Drug metabolism/resistance & 0.11 & 0.1 & 0.004 & 0.001 & 0.00 & \\
\hline AA664101 & Aldehyde dehydrogenase I family, member AI & Drug metabolism/resistance & 44.09 & 28.97 & 832 & 1137 & 0.49 & 0.006 \\
\hline AA031513 & Matrix metalloproteinase 7 (matrilysin, uterine) & Extracellular matrix & 20.68 & 17.23 & & & -0.06 & \\
\hline AA0560I3 & Microfibril-associated glycoprotein-2 & Extracellular matrix & 0.19 & 0.2 & & & 0.11 & \\
\hline AA479199 & Nidogen 2 & Extracellular matrix & 0.21 & 0.22 & 0.004 & 0.002 & -0.14 & \\
\hline AA458965 & Natural killer cell transcript 4 & Immune/inflammatory & 0.08 & 0.16 & & & -0.07 & \\
\hline AA682631 & Calcineurin A alpha & Kinase/phosphatase & 0.23 & 0.24 & & & -0.28 & \\
\hline AA431773 & Fatty acid desaturase I & Lipid metabolism & 0.18 & 0.21 & 0.005 & 0.007 & -0.59 & 0.001 \\
\hline AA432066 & Sarcoglycan, epsilon & Metabolism & 0.23 & 0.2 & & & -0.12 & \\
\hline AA434024 & Lanosterol synthase & Metabolism & 0.23 & 0.24 & 0.101 & 0.210 & -0.14 & \\
\hline AA40 I 137 & Lipocalin 2 (oncogene 24p3) & Oncogene & 10.98 & 8.89 & & & 0.12 & \\
\hline AA045436 & Basic leucine zipper transcription factor MafG & Oncogene & 5.07 & 4.33 & 1.370 & 4.820 & -0.15 & \\
\hline N63943 & Lysozyme (renal amyloidosis) & Antimicrobial & 10.01 & 8.18 & 2161.8 & 1817.5 & 0.55 & 0.002 \\
\hline AAI348 I 4 & TRAF family member-associated NFKB activator & Signal transduction & 4.83 & 4.44 & & & 0.55 & 0.013 \\
\hline AA598567 & Myelin gene expression factor 2 & Transcriptional coactivator & 5.02 & 4.85 & & & -0.05 & \\
\hline AA055486 & Tripartite motif-containing 29 & Transcription factor & 5.35 & 4.84 & & & -0.10 & \\
\hline Al0I7703 & Eukaryotic translation initiation factor 3 , subunit 3 & Translation/AA biochemistry & 5.11 & 4.25 & & & 0.45 & 0.013 \\
\hline R38343 & Protein tyrosine phosphatase, receptor type, G & Transmembrane receptor & 0.23 & 0.18 & & & -0.16 & \\
\hline T89391 & Caveolin 2 & Tumour suppressor & 0.19 & 0.22 & 0.025 & 0.067 & -0.01 & \\
\hline AAI I 2057 & KIAAOI 43 protein & Unknown & 6.73 & 5.57 & & & 0.40 & 0.031 \\
\hline AA282134 & OK/SW-cl.68 mRNA, complete cds & Unknown & 16.06 & $|0.5|$ & 774.2 & 568.4 & 0.12 & \\
\hline AA702350 & Autism-related protein I & Unknown & 0.06 & 0.08 & & & -0.04 & \\
\hline AA702949 & KIAA0443 gene product & Unknown & 0.11 & 0.16 & & & -0.06 & \\
\hline R4048 I & cDNA FLJ34699 fis, clone MESAN2002 I 86 & Unknown & 6.57 & 4.55 & & & 0.39 & 0.037 \\
\hline T62854 & Hypothetical protein FLJ22662 & Unknown & 0.14 & 0.19 & & & 0.06 & \\
\hline WI 6832 & Muscleblind-like protein MBLL39 & Unknown & 4.48 & 4.93 & 39.1 & 87.0 & 0.19 & \\
\hline
\end{tabular}

Genes with significant correlations between their expression levels and apoptotic response to camptothecin in a panel of 30 colorectal cancer cell lines are shown in bold font. ${ }^{a}$ The relative mRNA levels are shown for the 34 genes with a difference in expression greater than four-fold in LoVo vs L2 and L3 in the microarray experiments (mean of two

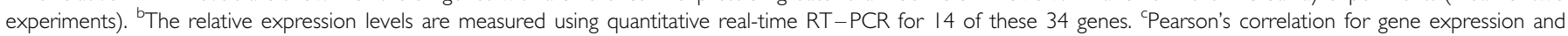
response to camptothecin in 30 colorectal cancer cell lines. 


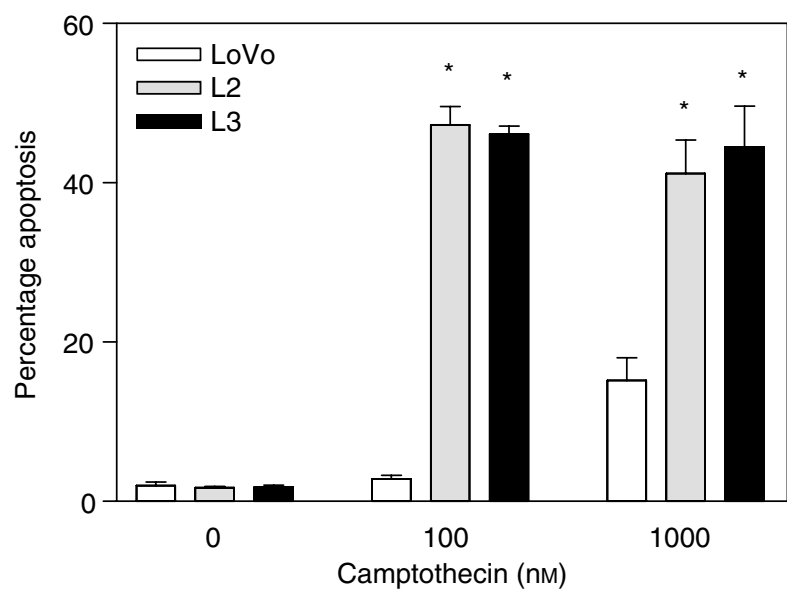

Figure I c-Myc overexpression sensitises colon cancer cells to camptothecin-induced apoptosis. The higher c-Myc levels and activity found in LoVo cells transfected with c-Myc (L2 and L3 cells) resulted in significant sensitisation to camptothecin-induced apoptosis, as demonstrated by PI staining and FACS analysis of cells exposed to 100 or 1000 nM camptothecin. The mean of three experiments \pm standard error of the mean is shown. Asterisks indicate significant differences (Student's t-test; $P<0.000$ I) between L2 or L3 cells and parental LoVo cells.

the results obtained using the LoVo system, the apoptotic response of TGR1 cells to camptothecin was significantly $(P<0.025)$ reduced in c-Myc-deficient HO15-19 isogenic cells exposed for $72 \mathrm{~h}$ to concentrations of camptothecin ranging from 25 to $100 \mathrm{nM}$ (Figure 2A, B). Moreover, when c-Myc expression was rescued in HO15-19 cells (HOmyc3 cells), their response to camptothecin returned to that observed in parental TGR1 cells (Figure 2A, B). Collectively, these results demonstrate an important role for $\mathrm{C}-\mathrm{Myc}$ in the apoptotic response to camptothecin.

\section{Role of p53 in c-Myc-imposed sensitisation to camptothecin-induced apoptosis}

c-Myc has been shown to regulate p53 levels both directly and through modulation of $\mathrm{p} 19^{\mathrm{ARF}}$ (Reisman et al, 1993; Tavtigian et al, 1994; Zindy et al, 1998). In addition, p53 has been reported to modulate the cellular response to several chemotherapeutic agents, including camptothecin and its derivatives (Gupta et al, 1997; Yang et al, 1996). Therefore, to investigate the possible role of p53 in the increased apoptotic response to camptothecin imposed by c-Myc overexpression, we assessed the relative levels of this tumour suppressor in p53 wild-type LoVo cells and c-Myc-transfected clones L2 and L3. c-Myc overexpression in L2 and L3 cells resulted in markedly increased p53 protein levels (Figure 3), consistent with the chemosensitive phenotype of these cells. Moreover, treatment of parental LoVo cells with 0.1 or $0.5 \mu \mathrm{M}$ camptothecin for $24 \mathrm{~h}$ lead to modestly increased p53 levels (Figure 4). However, Figure 4 shows that p53 levels in camptothecin-treated parental LoVo cells remained significantly lower than in untreated L2 and L3 cells. To directly assess the functional role of p53 in camptothecin-induced apoptosis, c-Myc-overexpressing L2 and L3 cells were exposed to camptothecin in the presence of doses of PFT- $\alpha$, a specific inhibitor of p53 (Komarov et al, 1999), that we have previously shown to inhibit 5FU-induced apoptosis in this system (Arango et al, 2001). Here, inhibition of p53 function resulted in over $50 \%$ reduction in the apoptotic response to $0.5 \mu \mathrm{M}$ camptothecin, demonstrating a p53-dependent component in the c-Myc-dependent increase in apoptosis following treatment with this agent (Figure 5).
A

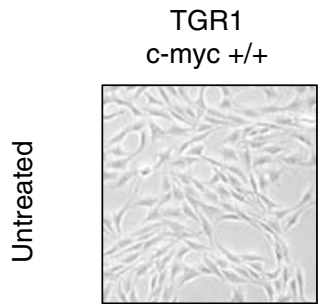

HO15-19

c-myc-1-

HOmyc-3
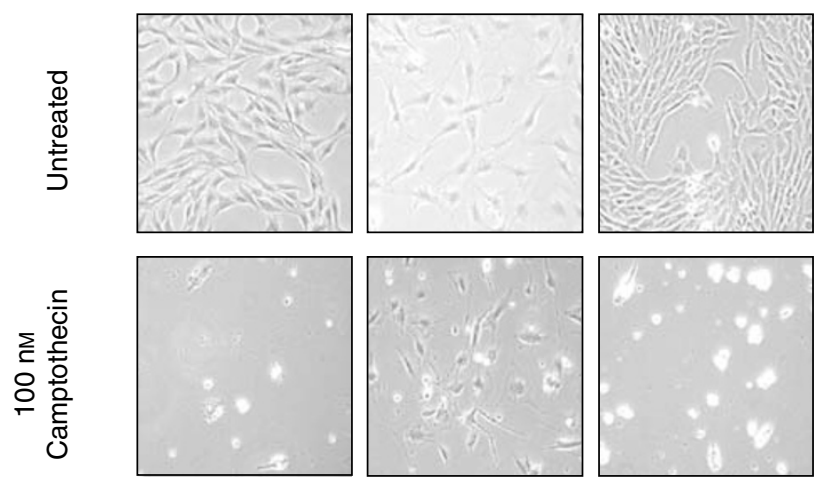

B

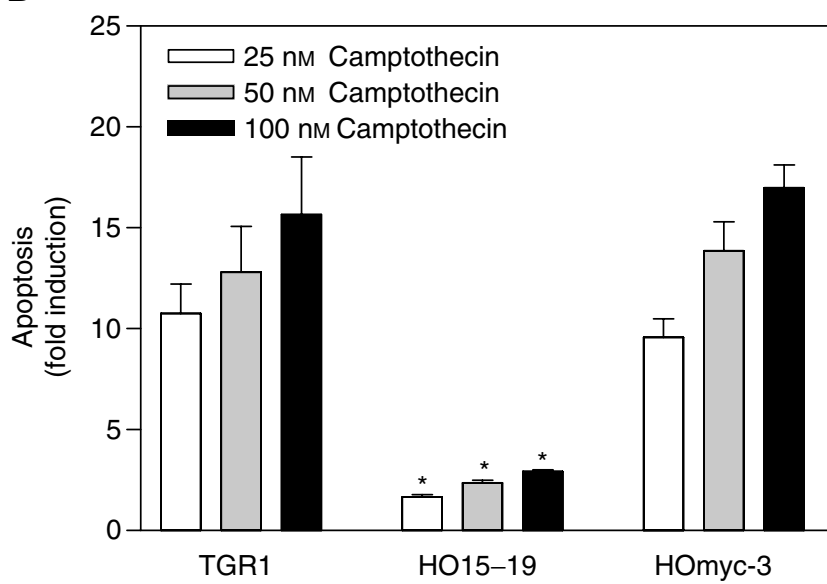

Figure 2 c-Myc levels modulate the apoptotic response to camptothecin in TGRI cells. Panel (A) shows representative phase-contrast micrographs of TGRI cells and derivatives exposed to I00 nM camptothecin for $72 \mathrm{~h}$. In panel (B), the apoptotic response to camptothecin was quantified by PI staining and FACS analysis. Targeted deletion of the c-Myc gene in TGRI cells (HOI5-19 cells) results in a significant reduction in camptothecin-induced apoptosis (A, B). Restoring c-Myc expression in cMyc-deficient HOI5-19 cells (HOmyc-3 cells) results in a significant increase in apoptosis. The mean of three experiments \pm standard error of the mean is shown in panel (B). Asterisks indicate significant differences (Student's t-test; $P<0.025$ ) between c-Myc null HOI5-19 cells and both parental TGRI cells and c-Myc rescue HOmyc-3 cells for a given dose.

\section{Role of $\mathrm{p} 21^{\text {Waf1/Cip1 }}$ in c-Myc-imposed sensitisation to camptothecin-induced apoptosis}

p53 can strongly induce apoptosis by transcriptionally regulating the expression of a number of key players in the apoptotic cascade (Miyashita et al, 1994). However, p53 can alternatively induce cell cycle arrest and promote DNA damage repair through upregulation of the cdk inhibitor p21 Waf1/Cip1 (el-Deiry et al, 1993). c-Myc overexpression in LoVo cells resulted in significantly increased p53

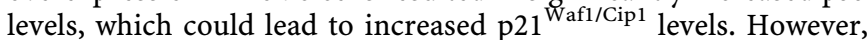
c-Myc has been shown to directly downregulate p $21^{\text {Waf1/Cip1 }}$ levels (Mitchell and El-Deiry, 1999; Gartel et al, 2001). Therefore, we decided to assess the overall effects of c-Myc overexpression on the transcriptional activity of the $\mathrm{p} 21^{\text {Waf1/Cip } 1}$ promoter. First, we investigated whether $\mathrm{c}-\mathrm{Myc}$ can reduce $\mathrm{p} 21^{\text {Waf1/Cip1 }}$ promoter activity in parental LoVo cells. Cotransfection of a c-Myc expression vector and a construct containing the $\mathrm{p} 21^{\text {Waf1/Cip } 1}$ promoter region upstream of a luciferase reporter gene $(\mathrm{p} 21 \mathrm{P}$ plasmid), demonstrated that c-Myc could effectively reduce the promoter activity of $\mathrm{p} 21^{\text {Waf1/Cip1 }}$ in LoVo cells (Figure 6A). Next, 
$\stackrel{\circ}{3}$

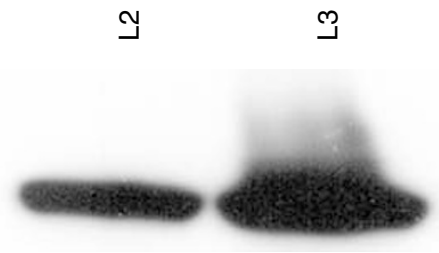

p53

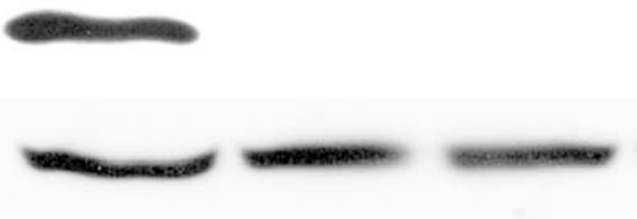

$\beta$-Actin

Figure 3 Effects of c-Myc overexpression on p53 and p2/Wafl/Cipl levels. Western blot analysis demonstrated that forced overexpression of cMyc in LoVo cells (L2 and L3 cells) results in increased p53 and reduced p2 I Wafl/Cipl protein levels.

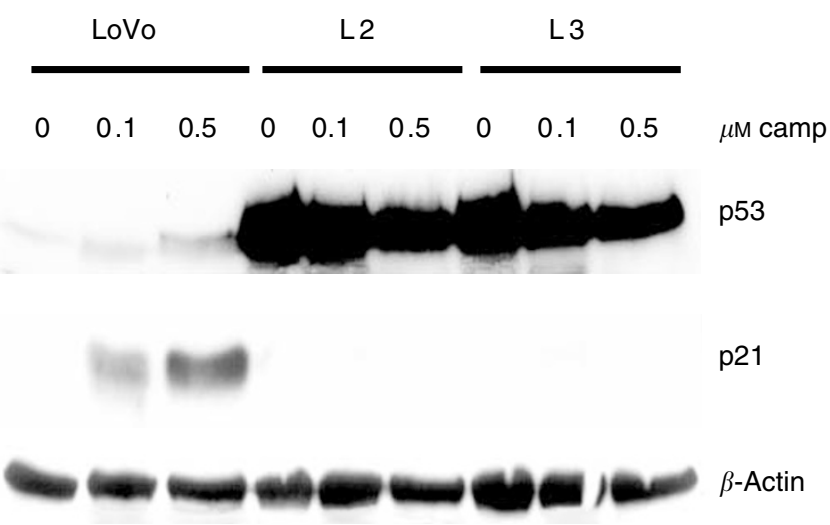

Figure 4 Effects of camptothecin treatment on p53 and p2/ Wafl/Cip I levels. Western blot analysis demonstrated that exposure to $0.1-0.5 \mu \mathrm{M}$ camptothecin for $24 \mathrm{~h}$ results in a modest induction of p53 and significant accumulation of $\mathrm{p} 2 \mathrm{I}^{\mathrm{Wafl} / \mathrm{Cip} /}$ in parental LoVo cells. Overexpression of cMyc in L2 and L3 cells completely abrogates upregulation of $p 21^{\text {Wafl/Cip I }}$ levels in response to camptothecin, despite the elevated p53 levels.

we compared $\mathrm{p} 21^{\mathrm{Waf} 1 / \mathrm{Cip} 1}$ promoter activity in parental LoVo cells and L2 and L3 cells showing elevated levels of c-Myc and p53. The promoter activity of $\mathrm{p} 21^{\text {Waf1/Cip1 }}$ was found to be significantly reduced in L2 and L3 cells compared to parental LoVo cells (1.75and 2.5-fold downregulation, respectively; Figure 6B). Consistent with the reduced transcriptional activity of the $\mathrm{p} 21^{\text {Waf1/Cip } 1}$ promoter, Western blot analysis demonstrated that the higher cMyc levels in LoVo transfectants (L2 and L3 cells) resulted in a significant reduction in $\mathrm{p} 21^{\mathrm{Waf} 1 / \mathrm{Cip} 1}$ protein (Figure 3 ), despite the higher p53 levels.

Importantly, although exposure of parental LoVo cells to 0.1 or $0.5 \mu \mathrm{M}$ camptothecin for $24 \mathrm{~h}$ resulted in upregulation of $\mathrm{p} 53$ and the p53 target gene $\mathrm{p} 21^{\text {Waf1/Cip1 }}, \mathrm{c}$-Myc-overexpressing L2 and L3 cells failed to upregulate $\mathrm{p} 21^{\mathrm{Waf1} / \mathrm{Cip} 1}$ protein levels in response to camptothecin treatment (Figure 4), strongly suggesting that p $21^{\text {Waf1/Cip1 }}$ levels could modulate apoptosis induced by camptothecin. To directly investigate this possibility, we used an engineered in vitro system where both alleles of the $\mathrm{p} 21^{\text {Waf1/Cip1 }}$ gene have been inactivated by targeted deletion in HCT116 cells, a colon cancer cell line with a wild-type p53 gene (Bunz et al, 1998). Inactivation of $\mathrm{p} 21^{\mathrm{Waf} 1 / \mathrm{Cip} 1}$ in these cells resulted in significantly $(P<0.004)$ increased sensitivity to apoptosis induced by camp-

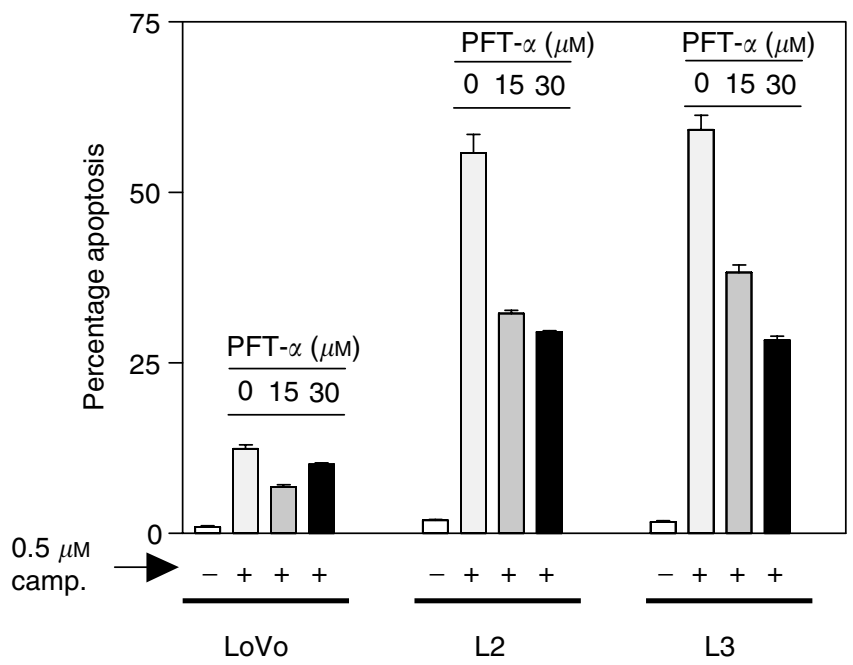

Figure 5 Role of p53 in the c-Myc imposed sensitisation to camptothecin-induced apoptosis. Exposure of $\mathrm{L} 2$ and $\mathrm{L} 3$ cells to camptothecin for $72 \mathrm{~h}$ in the presence of the specific inhibitor of $\mathrm{p} 53$ PFT- $\alpha$ demonstrated a p53-dependent component in their increased apoptotic response to this agent compared to parental LoVo cells. Mean of three experiments \pm standard error of the mean.

tothecin compared to parental wild-type $\mathrm{p} 21^{\text {Waf1/Cip } 1}$ HCT116 cells (Figure 7), further demonstrating a role for $\mathrm{p} 21^{\text {Waf1/Cip } 1}$ in regulating response of colon cancer cells to camptothecin.

\section{Identification of additional markers predicting response to camptothecin}

To identify additional genes that could serve as markers predicting apoptotic response to camptothecin, we measured the relative expression of 9216 sequences, in duplicate, in resistant LoVo cells, as well as in sensitive c-Myc-overexpressing L2 and L3 isogenic cells, using cDNA microarray analysis. The complete databases are available at http://sequence.aecom.yu.edu/bioinf/Augenlicht/default.html. First, to assess the background variability due to methodological and biological factors, we averaged the values for the two LoVo replicas and compared them to the average of another two different replicates of LoVo cells, and quantified the number of genes identified as differentially expressed as a function of selected cutoff values (Figure 8A). Using a conservative cutoff value of four-fold, there were six sequences that would be considered differentially expressed between the two pairs of LoVo replicas. However, using the same four-fold cutoff, LoVo $v s \mathrm{~L} 2$ and LoVo vs L3 differed in the expression of 63 and 47 genes, respectively. Moreover, 34 of those genes were differentially expressed over four-fold in both L2 and L3 compared to parental LoVo cells (Figure 8B; Table 1).

Utilisation of a four-fold change in expression for gene selection greatly minimises the probability of false positives. This was confirmed by quantitative real-time RT-PCR analysis of the relative expression levels of 14 of the 34 genes identified as differentially expressed by the microarray analysis. Good qualitative agreement was observed in changes in the levels of expression assessed by microarray and real-time RT - PCR for 13 out of the 14 genes tested by the two methods (Table 1). However, as observed in other studies (Sgroi et al, 1999; Menssen and Hermeking, 2002; Reinhold et al, 2003), the magnitude of the differences in gene expression assessed by quantitative real-time RT-PCR was greater than those observed using a cDNA microarray approach (Table 1).

Although a subset of the 34 genes differentially expressed over four-fold in LoVo cells and c-Myc-overexpressing L2 and L3 cells is likely to play a role in their differential apoptotic response to 
A

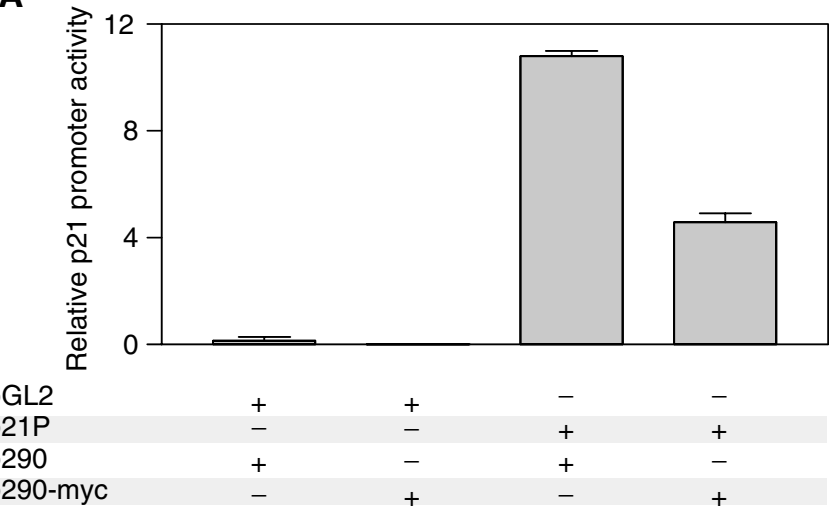

B

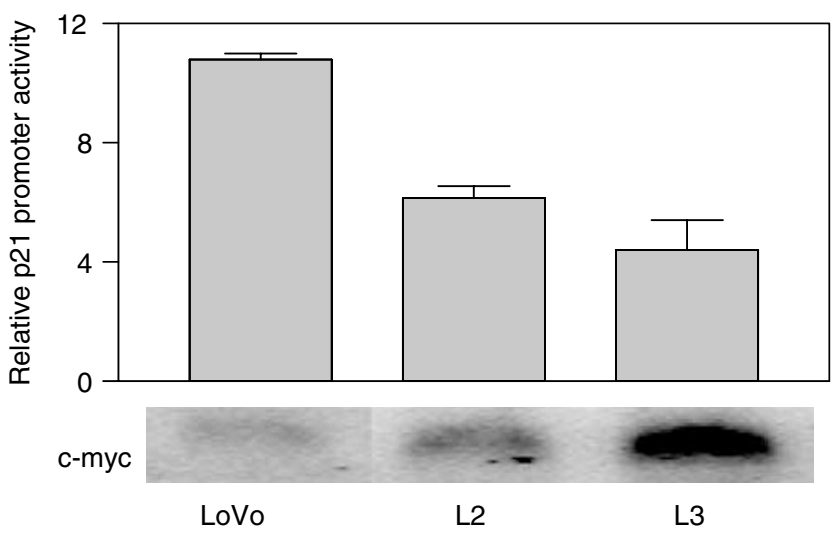

Figure 6 effects of c-Myc on p2/Wafl/Cipl promoter activity. (A) Parental LoVo cells were transfected with a vector containing the p2 I Wafl/Cip I promoter sequences upstream of a Firefly Luciferase reporter gene (p2IP) and a c-Myc expression vector (p290-Myc). This demonstrated a c-Myc-dependent reduction in $\mathrm{p} 2 \mathrm{I}^{\mathrm{Waf} / \mathrm{Cip} /}$ promoter activity when compared to cells transfected with P2IP and p290 empty vector (two-fold). Additional controls showed that transfection of LoVo cells with pGL2 (p2 I P without the p2 I Wafl/Cipl promoter sequence) and either p290 or p290-Myc resulted in minimal luciferase activity. (B) LoVo, L2 and L3 cells were transfected with $\mathrm{P} 2 \mathrm{IP}$ to measure the differences in promoter activity. The increased c-Myc levels in L2 and L3 resulted in a c-Myc dosedependent reduction of $\mathrm{p} 2 \mathrm{I}^{\mathrm{Wafl} / \mathrm{Cip} /}$ promoter activity. Relative c-Myc mRNA levels are shown underneath the histogram. Cotransfection with the plasmid TK-Renilla was used to correct for differences in transfection efficiency. The experiments were done three times in triplicate, and results of a representative experiment are shown.

camptothecin, elevated c-Myc levels have been shown to affect other phenotypic characteristics of colon cancer cells, including cell cycle progression and basic metabolism (Tikhonenko et al, 1996; Dang, 1999; Menssen and Hermeking, 2002). Therefore, the subset of genes that may be specific markers of response to camptothecin is not clear. To identify this subset of genes, we screened the expression of these 34 sequences in a separate microarray database containing the expression profile of 30 different colorectal cancer lines assessed using the same 9216sequence cDNA chips (Mariadason $e t$ al, 2003; the full database is available at $\mathrm{http}: / /$ sequence.aecom.yu.edu/bioinf/Augenlicht/default.html). In addition, we have determined the relative sensitivity of these cell lines to camptothecin-induced apoptosis (percent apoptosis after $72 \mathrm{~h}$ exposure to $1 \mu \mathrm{M}$ camptothecin; Mariadason et al, 2003). Of the 34 genes that varied in expression over fourfold in parental LoVo cells and c-Myc-overexpressing L2 and L3 cells, 10 showed a significant correlation $(R>0.39 ; P<0.037)$

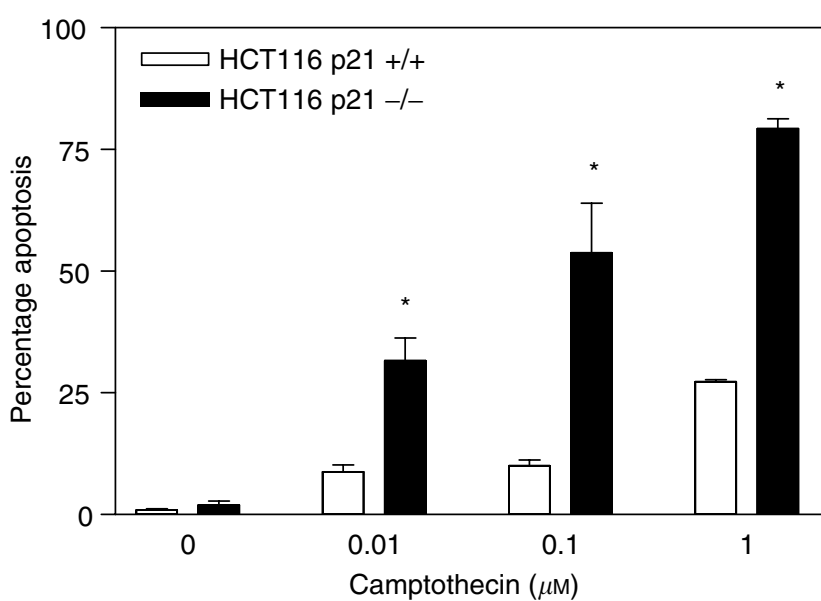

Figure 7 Role of $\mathrm{p} 2 \mathrm{l}$ in the apoptotic response to camptothecin Targeted inactivation of both alleles of p2l Wafl/Cipl in HCTII 6 colon cancer cells resulted in significant sensitisation to camptothecin-induced apoptosis. The mean of four different experiments \pm standard error of the mean is shown. Asterisks indicate significant differences (Student's t-test, $P<0.004)$ between apoptotic levels in HCTII6 p2I $+1+$ and $-1-$ for a given dose.

between expression levels and response to camptothecin in each of the 30 colorectal cancer cell lines in our panel (Table 1). As a control, we selected the 34 genes showing the least difference in expression between resistant LoVo cells and sensitive L2 and L3 cells. None of these genes showed a significant correlation between expression levels and apoptotic response to camptothecin in the panel of 30 colorectal cancer cell lines (not shown), highlighting the potential of the genes modulated by c-Myc as biomarkers of response to camptothecin.

\section{DISCUSSION}

The proto-oncogene c-Myc is overexpressed in approximately $70 \%$ of colorectal tumours (Erisman et al, 1985). Deregulation and overexpression of c-Myc and other oncogenes, in addition to having proliferative effects, is frequently associated with an apoptosis-prone phenotype, thus opening the possibility of therapeutic intervention (Prendergast, 1999). This study demonstrates that upregulation of c-Myc levels and activity in colon cancer cells results in markedly increased sensitivity to apoptosis induced by camptothecin. Forced overexpression of c-myc in LoVo colon cancer cells, induced significant accumulation of p53, and the increased apoptotic response to camptothecin was at least partially dependent upon p53 function. However, p53 can induce cell cycle arrest and facilitate DNA damage repair through the transcriptional activation of the cdk inhibitor p $21^{\text {Waf } 1 / \text { Cip1. The }}$ factors determining a p53-dependent apoptotic or cytostatic response to cytotoxic insult remain unclear. Recently, elevated cMyc levels have been identified as one such factor favouring a p53dependent apoptotic response (Seoane et al, 2002). Here we show that despite the elevated p53 levels in c-Myc-overexpressing L2 and L3 cells compared to parental LoVo cells, c-Myc directly repressed the transcriptional activity of $\mathrm{p} 21^{\text {Wafl/Cip1 }}$ and resulted in reduced p $21^{\text {Waf1/Cip1 }}$ protein levels. Moreover, although camptothecin treatment resulted in $\mathrm{p} 21^{\text {Wafl/Cip1 }}$ accumulation in resistant LoVo cells, sensitive L2 and L3 cells failed to upregulate $\mathrm{p} 21^{\text {Waf } 1 / \text { Cip1 }}$ levels in the presence of camptothecin. The functional relevance of this finding was further demonstrated using an isogenic in vitro system in which both alleles of $\mathrm{p} 21^{\text {Wafl/CipP }}$ were inactivated by homologous recombination in HCT116 cells. Inactivation of p2 $1^{\text {Waf1/Cip } 1}$ in HCT116 cells resulted in significantly increased 
A

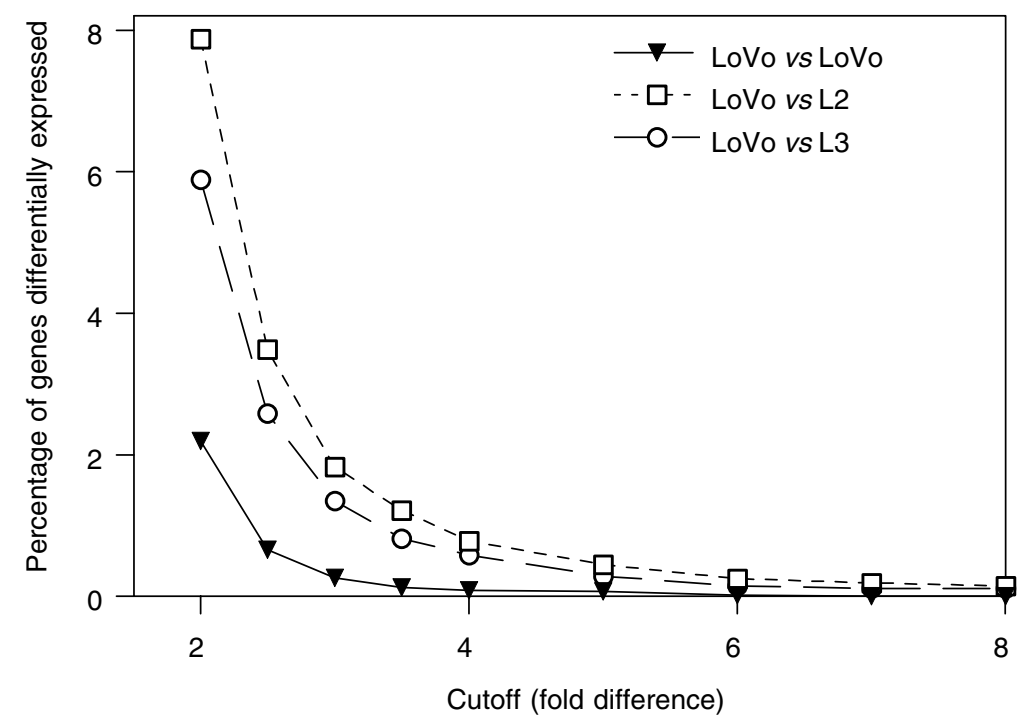

B

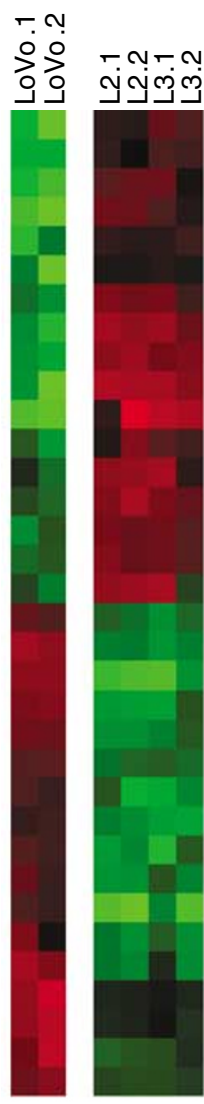

Lectin, galactoside-binding, soluble, 4 (galectin 4)

ESTs

Lysozyme (renal amyloidosis)

Glutaminyl-peptide cyclotransferase (glutaminyl cyclase)

$\mathrm{C} 3 \mathrm{H}$-type zinc-finger protein; similar to Drosophila melanogaster muscleblind B protein

Myelin gene expression factor 2

KIAA0143 protein

Myelin basic protein

Lipocalin 2 (oncogene 24p3)

Matrix metalloproteinase 7 (matrilysin, uterine)

Aldehyde dehydrogenase 1 , soluble

TRAF family member-associated NFKB activator

Eukaryotic translation initiation factor 3 , subunit 3 (gamma, $40 \mathrm{kDa}$ )

cDNA DKFZp564B1264 (from clone DKFZp564B1264)

Ataxia-telangiectasia group $D$-associated protein

$\mathrm{v}$-maf musculoaponeurotic fibrosarcoma (avian) oncogene family, protein $\mathrm{G}$

ESTs, weakly similar to KIAA0872 protein (Homosapiens)

Sarcoglycan, epsilon

Calbindin1 $(28 \mathrm{kDa})$

KIAA0442 protein

KIAA0443 gene product

ATP-binding cassette, subfamily A (ABC1), member 3

Lanosterol synthase (2,3-oxidosqualene-lanosterol cyclase)

Cadherin 17, LI cadherin (liver-intestine)

ESTs

CGI-43 protein

Glutathione S-transferase M4

Natural killer cell transcript 4

Caveolin 2

Coagulation factor C (Limulus polyphemus) homology (cochlin)

Microfibril-associated glycoprotein-2 MAGP-2 mRNA, complete cds

Nidogen 2

cDNA: FLJ22662 fis, clone HSI08080

Protein phosphatase 3 (formerly 2B), catalytic subunit, alpha isoform (calcineurin A alpha)

Fold difference

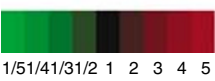

Figure 8 cDNA microarray analysis of LoVo and isogenic L2 and L3 cells overexpressing c-Myc. (A) The number of genes identified as differentially expressed is a function of the cutoff used. Selection of a stringent cutoff value of four-fold reduces the number of false positives expected when assessing differences in gene expression between LoVo and L2/L3 cells. (B) TreeView image showing the expression profile of the 34 genes with over four-fold expression difference between LoVo and L2/L3 that characterise camptothecin-resistant and -sensitive cells. Both replicas are shown. Red and green indicate genes that are over-represented and under-represented, respectively, relative to the reference RNA used (see Materials and Methods).

apoptosis following camptothecin treatment compared to p21 $1^{\text {Waf1/Cip1 } 1}$ wild-type parental HCT116 cells. Collectively, these studies identified the c-Myc-imposed reduction in $\mathrm{p} 21^{\text {Wafl/Cip1 }}$ levels as an important factor determining the increased sensitivity to camptothecin-induced apoptosis associated with elevated c-Myc levels. 
Despite significant progress in the identification of markers predicting response to other chemotherapeutic agents commonly used in the treatment of colorectal malignancies, namely, 5FU and oxaliplatin (Augenlicht et al, 1997; Salonga et al, 2000; Arango et al, 2001, 2003; Park et al, 2001; Shirota et al, 2001), there is a great need for clinical predictors of response to camptothecin derivatives. The capability of predicting response to the chemotherapeutic agents available for the treatment of colorectal cancer would allow tailoring of treatment to individual patients, thus maximising the probability of optimal response to therapy. Here we identified $\mathrm{c}-\mathrm{Myc}$ as a marker predicting response to camptothecin. Moreover, dissection of the molecular mechanisms responsible for the c-Myc-imposed sensitisation to camptothecin demonstrated the key role of $\mathrm{p} 21^{\mathrm{Waf} 1 / \mathrm{Cip}^{1}}$ in determining response of colon cancer cells to this agent, and pointed at this cdk inhibitor as an additional predictor of response.

To gain further insight into the differences between colon cancer cells that vary in their apoptotic response to camptothecin, and to identify additional markers that could help recognise tumours that vary in their response to this agent, we assessed the level of expression of 9216 sequences in resistant LoVo cells, and in sensitive L2 and L3 derivatives, using cDNA microarray analysis. This identified 34 genes that varied in expression over four-fold in parental LoVo cells and c-Myc-overexpressing L2 and L3 cells. To determine which of these 34 genes are effective predictors of the apoptotic response to camptothecin, we utilised a database containing the levels of expression of the same 9216 sequences in a panel of 30 different colorectal cancer cell lines using cDNA microarray analysis. In addition, we have also determined the relative sensitivity of these 30 cell lines to camptothecin. To identify those sequences associated with

\section{REFERENCES}

Arango D, Augenlicht LH (2001) New approaches to colorectal cancer treatment. In Recent Research Developments in Cancer, Vol. 3 pp $385-$ 395. Trivandrum: Transworld Research Network

Arango D, Corner GA, Wadler S, Catalano PJ, Augenlicht LH (2001) c-myc/ p53 interaction determines sensitivity of human colon carcinoma cells to 5-fluorouracil in vitro and in vivo. Cancer Res 61: 4910-4915

Arango D, Wilson AJ, Mariadason JM, Corner GA, Arañes MJ, Nicholas C, Augenlicht LH (2003) Molecular mechanisms of action and prediction of response to oxaliplatin in colorectal cancer cells. (submitted)

Augenlicht LH, Wadler S, Corner G, Richards C, Ryan L, Multani AS, Pathak S, Benson A, Haller D, Heerdt BG (1997) Low-level c-myc amplification in human colonic carcinoma cell lines and tumors: a frequent, p53-independent mutation associated with improved outcome in a randomized multi-institutional trial. Cancer Res 57: 1769-1775

Augeron C, Laboisse CL (1984) Emergence of permanently differentiated cell clones in a human colonic cancer cell line in culture after treatment with sodium butyrate. Cancer Res 44: 3961 - 3969

Bunz F, Dutriaux A, Lengauer C, Waldman T, Zhou S, Brown JP, Sedivy JM, Kinzler KW, Vogelstein B (1998) Requirement for p53 and p21 to sustain G2 arrest after DNA damage. Science 282: 1497 - 1501

Cunningham D, Pyrhonen S, James RD, Punt CJA, Hickish TF, Heikkila R, Johannesen TB, Starkhammar H, Topham CA, Awad L (1998) Randomised trial of irinotecan plus supportive care versus supportive care alone after fluorouracil failure for patients with metastatic colorectal cancer. The Lancet 352: 1413-1418

Dang CV (1999) c-Myc target genes involved in cell growth, apoptosis, and metabolism. Mol Cell Biol 19: 1-11

Datto MB, Yu Y, Wang XF (1995) Functional analysis of the transforming growth factor beta responsive elements in the WAF1/Cip1/p21 promoter. J Biol Chem 270: $28623-28628$

Devine PL, Birrell GW, Whitehead RH, Harada H, Xing PX, McKenzie IF (1992) Expression of MUC1 and MUC2 mucins by human tumor cell lines. Tumour Biol 13: 268-277

Douillard JY, Cunningham D, Roth AD, Navarro M, James RD, Karasek P, Jandik P, Iveson T, Carmichael J, Alakl M, Gruia G, Awad L, Rougier P differences in sensitivity to camptothecin, we assessed whether each one of the 34 genes differentially expressed in resistant LoVo and sensitive L2/L3 cells showed a significant correlation between expression levels and camptothecin-induced apoptosis in the 30 cell lines in our panel. This identified 10 genes with significant expression/response correlations $(R>0.39$ and $P<0.037$; Table 1$)$. This list of candidate genes capable of predicting response to camptothecin contains genes involved in drug metabolism/ resistance, signal transduction, protein translation and general metabolism (see Table 1). At least some of these genes have been shown to vary in expression in colorectal tumours, including GSTM1, ALDH and lysozyme (Yuen et al, 1998; Saadat and Saadat, 2001), and could play a functional role in the cellular response to camptothecin and its derivatives. Therefore, in addition to their value as markers predicting response to camptothecin, each of these genes could represent a new target for therapeutic intervention.

\section{ACKNOWLEDGEMENTS}

The plasmids p21P, p290-Myc $(2,3)$ and TGR1 cells and derivatives were kindly provided by Dr Wang (Duke University, NC, USA), Dr Dalla-Favera (Columbia University, NY, USA) and Dr Sedivy (Brown University, RI, USA), respectively. We also thank Aldo Massimi and Dr Geoff Childs of the Albert Einstein Microarray Facility for their assistance, and Dr Barbara Heerdt and Dr Edward Schwartz for critical reading of the manuscript. This work was supported in part by National Cancer Institute grants CA81328, CA88104 and P30-13330.
(2000) Irinotecan combined with fluorouracil compared with fluorouracil alone as first-line treatment for metastatic colorectal cancer: a multicentre randomised trial. Lancet 355: $1041-1047$

el-Deiry WS, Tokino T, Velculescu VE, Levy DB, Parsons R, Trent JM, Lin D, Mercer WE, Kinzler KW, Vogelstein B (1993) WAF1, a potential mediator of p53 tumor suppression. Cell 75: 817-825

Erisman MD, Rothberg PG, Diehl RE, Morse CC, Spandorfer JM, Astrin SM (1985) Deregulation of c-myc gene expression in human colon carcinoma is not accompanied by amplification or rearrangement of the gene. Mol Cell Biol 5: $1969-1976$

Gartel AL, Ye X, Goufman E, Shianov P, Hay N, Najmabadi F, Tyner AL (2001) Myc represses the p21(WAF1/CIP1) promoter and interacts with Sp1/Sp3. Proc Natl Acad Sci USA 98: 4510-4515

Gupta M, Fan S, Zhan Q, Kohn KW, O'Connor PM, Pommier Y (1997) Inactivation of p53 increases the cytotoxicity of camptothecin in human colon HCT116 and breast MCF-7 cancer cells. Clin Cancer Res 3: $1653-$ 1660

Harvey J, Bonnem E, Grady K, Goodman A, Schein P (1985) Phase II study of daunorubicin in previously untreated patients with advanced colorectal carcinoma. Med Pediatr Oncol 13: 30-31

Komarov PG, Komarova EA, Kondratov RV, Christov-Tselkov K, Coon JS Chernov MV, Gudkov AV (1999) A chemical inhibitor of p53 that protects mice from the side effects of cancer therapy. Science 285: 1733 1737

Mariadason JM, Arango D, Shi Q, Wilson AJ, Corner GA, Nicholas C, Aranes MJ, Schwartz EL, Lesser M (2003) Gene expression profiling based prediction of response of colon carcinoma cells to chemotherapeutic agents. Cancer Res (in press)

Mariadason JM, Corner GA, Augenlicht LH (2000) Genetic reprogramming in pathways of colonic cell maturation induced by short chain fatty acids: comparison with trichostatin $\mathrm{A}$, sulindac, and curcumin and implications for chemoprevention of colon cancer. Cancer Res 60: 4561-4572

Mateyak MK, Obaya AJ, Adachi S, Sedivy JM (1997) Phenotypes of c-Mycdeficient rat fibroblasts isolated by targeted homologous recombination. Cell Growth Differ 8: 1039-1048 
Menssen A, Hermeking H (2002) Characterization of the c-MYC-regulated transcriptome by SAGE: identification and analysis of c-MYC target genes. Proc Natl Acad Sci USA 99: 6274-6279

Mitchell KO, El-Deiry WS (1999) Overexpression of c-Myc inhibits p21WAF1/CIP1 expression and induces S-phase entry in12-O-tetradecanoylphorbol-13-acetate (TPA)-sensitive human cancer cells. Cell Growth Differ 10: $223-230$

Miyashita T, Krajewski S, Krajewska M, Wang HG, Lin HK, Liebermann DA, Hoffman B, Reed JC (1994) Tumor suppressor p53 is a regulator of bcl-2 and bax gene expression in vitro and in vivo. Oncogene 9: 17991805

O'Dwyer PJ, Stevenson JP (1998) Chemotherapy of advanced colorectal cancer. In Gastrointestinal Oncology, Cancer Treatment and Research, Benson AL (ed) pp 111 -152. Norwell: Kluwer Academic Publishers

Park DJ, Stoehlmacher J, Zhang W, Tsao-Wei DD, Groshen S, Lenz HJ (2001) A Xeroderma pigmentosum group D gene polymorphism predicts clinical outcome to platinum-based chemotherapy in patients with advanced colorectal cancer. Cancer Res 61: 8654-8658

Prendergast GC (1999) Mechanisms of apoptosis by c-Myc. Oncogene 18: $2967-2987$

Reed JC, Haldar S, Cuddy MP, Croce C, Makover D (1989) Deregulated BCL2 expression enhances growth of a human B cell line. Oncogene 4: $1123-1127$

Reinhold WC, Kouros-Mehr H, Kohn KW, Maunakea AK, Lababidi S, Roschke A, Stover K, Alexander J, Pantazis P, Miller L, Liu E, Kirsch IR, Urasaki Y, Pommier Y, Weinstein JN (2003) Apoptotic susceptibility of cancer cells selected for camptothecin resistance: gene expression profiling, functional analysis, and molecular interaction mapping. Cancer Res 63: $1000-1011$

Reisman D, Elkind NB, Roy B, Beamon J, Rotter V (1993) c-Myc transactivates the p53 promoter through a required downstream CACGTG motif. Cell Growth Differ 4: 57-65

Saadat I, Saadat M (2001) Glutathione S-transferase M1 and T1 null genotypes and the risk of gastric and colorectal cancers. Cancer Lett 169: $21-26$

Salonga D, Danenberg KD, Johnson M, Metzger R, Groshen S, Tsao-Wei DD, Lenz HJ, Leichman CG, Leichman L, Diasio RB, Danenberg PV
(2000) Colorectal tumors responding to 5-fluorouracil have low gene expression levels of dihydropyrimidine dehydrogenase, thymidylate synthase, and thymidine phosphorylase. Clin Cancer Res 6: $1322-1327$

Seoane J, Le HV, Massague J (2002) Myc suppression of the p21(Cip1) Cdk inhibitor influences the outcome of the p53 response to DNA damage. Nature 419: $729-734$

Sgroi DC, Teng S, Robinson G, LeVangie R, Hudson Jr JR, Elkahloun AG (1999) In vivo gene expression profile analysis of human breast cancer progression. Cancer Res 59: 5656-5661

Shirota Y, Stoehlmacher J, Brabender J, Xiong YP, Uetake H, Danenberg KD, Groshen S, Tsao-Wei DD, Danenberg PV, Lenz HJ (2001) ERCC1 and thymidylate synthase mRNA levels predict survival for colorectal cancer patients receiving combination oxaliplatin and fluorouracil chemotherapy. J Clin Oncol 19: 4298-4304

Tavtigian SV, Zabludoff SD, Wold BJ (1994) Cloning of mid-G1 serum response genes and identification of a subset regulated by conditional myc expression. Mol Biol Cell 5: 375-388

Tibbetts LM, Chu MY, Vezeridis MP, Miller PG, Tibbetts LL, Poisson MH, Camara PD, Calabresi P (1988) Cell culture of the mucinous variant of human colorectal carcinoma. Cancer Res 48: 3751 - 3759

Tikhonenko AT, Black DJ, Linial ML (1996) Viral Myc oncoproteins in infected fibroblasts down-modulate thrombospondin-1, a possible tumor suppressor gene. J Biol Chem 271: 30741 - 30747

Whitehead RH, Macrae FA, St John DJ, Ma J (1985) A colon cancer cell line (LIM1215) derived from a patient with inherited nonpolyposis colorectal cancer. J Natl Cancer Inst 74: 759-765

Yang B, Eshleman JR, Berger NA, Markowitz SD (1996) Wild-type p53 protein potentiates cytotoxicity of therapeutic agents in human colon cancer cells. Clin Cancer Res 2: 1649-1657

Yuen ST, Wong MP, Chung LP, Chan SY, Cheung N, Ho J, Leung SY (1998) Up-regulation of lysozyme production in colonic adenomas and adenocarcinomas. Histopathology 32: 126-132

Zindy F, Eischen CM, Randle DH, Kamijo T, Cleveland JL, Sherr CJ, Roussel MF (1998) Myc signaling via the ARF tumor suppressor regulates p53-dependent apoptosis and immortalization. Genes Dev 12: $2424-2433$ 